\title{
A dialogical self-approach to understanding teacher iden- tity in times of educational innovations
} Un enfoque dialógico del self para comprender la identidad del profesor en tiempos de innovaciones educativas

\author{
Carles Monereo \\ Universitat Autónoma de Barcelona \\ Antoni Badia \\ Universitat Oberta de Catalunya
}

\begin{abstract}
Scientific literature has repeatedly demonstrated the difficulty of implementing relevant and sustained educational innovations. In this article, we defend that a deep and permanent change can only be achieved if the professional identity of the teachers participating in the innovation is changed. From the perspective of the Dialogical Self Theory, this change of identity implies a change in the I-positions of the individual participants, but also of their identity as a team or We-position.
\end{abstract}

Keywords: Education; Educational personnel; Teacher Professional Identity; Dialogical Self Theory

\section{Resumen}

La literatura científica ha demostrado repetidamente la dificultad de implementar innovaciones educativas relevantes y sostenidas. En este artículo, sostenemos que sólo se puede lograr un cambio profundo y permanente si se cambia la identidad profesional de los docentes que participan en la innovación. Desde la perspectiva de la Teoría del Self Dialógico, este cambio de identidad implica un cambio en las I-posiciones de los participantes individuales, pero también de su identidad como equipo o We-posición.

Palabras clave: Educación; Personal docente; Identidad profesional del profesor; Teoría del self dialógico 


\section{INTRODUCTION}

Changing the practices of an education practitioner, such as a teacher, an advisor or the head of an educational centre, is not easy. Given that changes in individual practices also affect education as a whole and its institutional culture, such a transformation is a very complex task if not somewhat idealistic. Changes intended to be sustained over time cannot be superficial and should not merely involve establishing a set of general pedagogical principles anticipated to be readily accepted by participants.

Permanent, deep and sufficient changes in professional practices alter an individual's sense of self, his/her identity, and the identity of the group from which he or she is part (Gaete Vergara, 2018). These modifications also apply to intended changes designed to embrace the introduction of new educational methods and techniques. While promoting changes based in constructivist principles through cooperative work, problem-solving or educational projects might help, consequences on changing practices are reduced or worse can result in a professional identity crisis unless such efforts are accompanied by measures affecting a participant's personal, professional and group identity (Collet-Sabe, 2017; Sadovnikova, \& Mirzaahmedov, 2019; Twyford, Fevre, \& Timperley, 2017).

The scientific literature has repeatedly evidenced the difficulty of implementing relevant and sustained educational innovations. Despite enthusiasm and initial support from the educational community, obstacles are common, and results are usually limited. In addition, resulting feelings of disappointment have motivated a reluctance to change and to attack innovations and demand a return to more traditional teaching methods based on the authority of the teacher and the use of traditional conferences. From our point of view, what is missing is a professional development model that leads the desired direction of innovation, which cannot be reduced to the will or knowledge of individual teachers (Hayward \& Spencer, 2010; Ivanova \& Popova, 2017). Concepts, strategies, and feelings related to repeated practices over the years are deeply rooted and difficult to modify through sheer will (Westaway \& Graven, 2019). This is true for both teachers and the entire educational community, students, parents, and administrators (for the Hispanic context, we recommend reviewing Rivas, 2017, and for the Anglo-Saxon context, the excellent reflections of Heick, 2019).

In this paper, we argue that changes in teachers' identity, both individually and collectively, serve as excellent indicators for assessing the quality of educational innovations. To achieve this goal, we first compare current approaches to teacher training and innovation while highlighting the advantages of a dia- 
logical approach. Second, we defend the crucial importance of educational innovations for promoting identity changes, and third, we provide an example of how to use a dialogical analysis to evaluate the effects of a case, both realistic and plausible, of educational innovation.

\section{CURRENT PSYCHOLOGICAL PERSPECTIVES OF TEACHER LEARNING}

Over the last twenty years, two different perspectives on teacher learning can be identified from the academic field of Educational Psychology. We will refer to these perspectives as teacher knowledge development and teacher competencies development.

Contributions based on teacher knowledge development focus on the study of theoretical concepts such as teachers' practical theories (Levin \& He, 2008), teachers' beliefs (Ertmer, 2005), teachers' conceptions (Abd-El-Khalick \& Lederman, 2000), teachers' approaches (Trigwell, Prosser, \& Waterhouse, 1999), teachers' attitudes (Avramidis \& Norwich, 2002), and teachers' perceptions (Beijaard, Verloop, \& Vermunt, 2000).

The teacher knowledge development perspective covers at least three different learning mechanisms: teachers' acquisition of knowledge, teachers' construction of knowledge, and teachers' co-construction of meanings (Putnam \& Borko, 2000).

\begin{tabular}{ccccc}
\hline Learning & $\begin{array}{c}\text { Programme } \\
\text { content }\end{array}$ & $\begin{array}{c}\text { Purpose of teacher } \\
\text { education }\end{array}$ & $\begin{array}{c}\text { Instructional } \\
\text { approach }\end{array}$ \\
\hline $\begin{array}{c}\text { Acquisition of } \\
\text { academic } \\
\text { knowledge }\end{array}$ & Predetermined & $\begin{array}{c}\text { To provide access to } \\
\text { content }\end{array}$ & Direct instruction \\
& Open & $\begin{array}{c}\text { To support teachers' } \\
\text { learning processes }\end{array}$ & $\begin{array}{c}\text { Guided learning } \\
\text { through specific } \\
\text { learning assignments }\end{array}$ \\
\hline \multirow{2}{*}{$\begin{array}{c}\text { lonstruction of } \\
\text { knowledge }\end{array}$} & $\begin{array}{c}\text { Social co- } \\
\text { construction of } \\
\text { meanings }\end{array}$ & Negotiated & $\begin{array}{c}\text { To socially share } \\
\text { meanings }\end{array}$ & $\begin{array}{c}\text { Participation in } \\
\text { communities through } \\
\text { social interaction }\end{array}$ \\
\hline
\end{tabular}

Table 1. Teacher knowledge development perspective

The first mechanism, acquisition of academic knowledge, refers to how teachers can extend their existing knowledge by acquiring predetermined content, usually through direct instruction. Early cognitive theories typically characterized teacher learning in this way and focused their analysis on expanding teachers' knowledge, connections between concepts and overarching ideas guiding teaching decisions (see Table 1) (Rovegno, 1992). 
The second mechanism, construction of knowledge, refers to how a teacher's existing knowledge can be qualitatively modified and enriched, usually through methods such as guided learning during learning assignments. In this case, teacher learning is understood and explained using different types of conceptual frameworks such as: a) teacher cognition theory and the conceptual change model, which explain how teachers modify their understanding and views about, for example, the nature of science (Abd-El-Khalick \& Akerson, 2004); b) situated learning theory, which focuses on how teachers gain access to the complex, critical thinking processes used by expert teachers in their classrooms (Leaman \& Flanagan, 2013); or c) the Vygotskian approach, which analyses how teachers can learn within their zones of proximal development (Warford, 2011).

The last mechanism included in this perspective, social co-construction of meanings, aims to explain how teachers, as participants in a group, community or network of professionals, can negotiate and build a socially shared meaning from their individual existing knowledge. This teacher learning mechanism usually operates when teachers participate in a social milieu such as a learning community and are engaged in the negotiation of meanings with other teachers. Teacher learning as social participation is framed by the socioconstructivist approach, which explains mechanisms of learning in communities of practice (Beijaard, 2017; Cochran-Smith \& Lytle, 1999).

Research on these three teachers learning mechanisms shares the common goal of learning more about teachers' knowledge and the process through which teachers adopt new perspectives. The first two mechanisms focus on the individual level while the third examines the interpersonal and social levels. Despite the enormous amount of psychological research that has been carried on these learning mechanisms, two issues have not been analysed in depth: a) relationships between different aspects of teacher learning (e.g., teachers' beliefs, views, attitudes, or theories) and b) relationships between knowledge, thinking, and classroom behaviour.

The teacher competencies development perspective focuses on acquiring and practising a set of skills to carry out teaching (Jennings \& Greenberg, 2009), promote reflective teachers (Kim, Xie, \& Cheng, 2017), and regulate and assess teachers' competencies (Admiraal, Hoeksma, van de Kamp, \& van Duin, 2011) (see Table 2).

The first mechanism of this perspective, practising teaching skills, involves enhancing the quality of teaching and often takes into account classifications of teachers' competencies according to a set of teaching roles described in terms of standards and developed by means of teacher skills training programmes. 


\begin{tabular}{|c|c|c|c|c|}
\hline & $\begin{array}{l}\text { Learning } \\
\text { mechanism }\end{array}$ & $\begin{array}{l}\text { Programme } \\
\text { content }\end{array}$ & $\begin{array}{c}\text { Purpose of } \\
\text { teacher education }\end{array}$ & $\begin{array}{l}\text { Instructional } \\
\text { approach }\end{array}$ \\
\hline \multirow{3}{*}{ 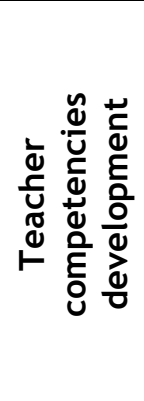 } & $\begin{array}{l}\text { Practising } \\
\text { teaching skills }\end{array}$ & $\begin{array}{l}\text { A set of teaching } \\
\text { standardized skills }\end{array}$ & $\begin{array}{l}\text { To improve the } \\
\text { quality of teaching }\end{array}$ & $\begin{array}{l}\text { Teacher skills } \\
\text { training }\end{array}$ \\
\hline & $\begin{array}{l}\text { Reflection on } \\
\text { teaching } \\
\text { competencies }\end{array}$ & $\begin{array}{l}\text { In-context use of } \\
\text { competencies }\end{array}$ & $\begin{array}{l}\text { To develop } \\
\text { reflective teachers }\end{array}$ & Strategic teaching \\
\hline & $\begin{array}{c}\text { Self-regulation of } \\
\text { teaching } \\
\text { competencies }\end{array}$ & $\begin{array}{l}\text { Regulated use of } \\
\text { competencies } \\
\text { through inquiry }\end{array}$ & $\begin{array}{l}\text { To further } \\
\text { teachers' } \\
\text { professional } \\
\text { development }\end{array}$ & Inquiry teaching \\
\hline
\end{tabular}

Table 2. Teacher competencies development perspective

Some examples of this approach include in-service training on teachers' competencies in classroom management in secondary schools (Piwowar, Thiel, \& Ophardt, 2013) and a preservice teacher learning course on instructional planning aligned with USA national standards for teacher preparation (Peterson \& Bond, 2004).

The second mechanism, reflection on teaching competencies, aims for the development of a reflexive teacher (Hatton \& Smith, 1995) through the use of instruments and strategies to promote different types and phases of teacher reflection. Examples of ways to promote reflection among teacher include the use of video recordings and related instructional strategies (Blomberg, Sherin, Renkl, Glogger, \& Seidel, 2014) and the use of written text in student teacher portfolios (Toom, Husu, \& Patrikainen, 2015).

The third mechanism, self-regulation of teaching competencies, refers to the process of professional teaching development designed to promote selfregulation in teaching through metacognitive processes such as planning, monitoring and adjusting. This may involve teachers' engagement in processes of collaborative inquiry to promote shifts in practice as part of their professional development via recursive cycles of goal-directed, self-regulated inquiry among teachers (Butler \& Schnellert, 2012).

Both psychological perspectives of professional teacher learning focus on teachers' development of professional "assets" defined as desired outcomes that must be learned by teachers. Three critical limitations of both perspectives include the following. a) They assume accumulation and linearity in moving from a novice level to an expert level; b) they do not explain how the development of an asset can affect the development of other assets, and c) they do not clarify how teachers make sense of their teaching practices. New psy- 
chological perspectives focusing on teachers' identities and based on the dialogical self-approach may provide us with a new perspective that overcomes these limitations (Akkerman \& Meijer, 2011).

\section{TEACHERS' CHANGES IN PROFESSIONAL IDENTITY FROM THE DIALOGICAL SELF- APPROACH}

The dialogical self-approach defines a human being as a subjective person who can make sense of the world due the dialogic nature of the self. The subjective dialogical self of a particular teacher can be described as the mental space in which, through language and inner speech, a teacher develops meaningful personal understandings of the professional world and his/her own way of being a teacher in a particular professional scenario (Hermans, 2001). This mental space is populated by different voices, one's own voice and the voices of others, which interact and dialogue with each other in trying to make sense of the steady flow of professional information and the professional activities in which one participates.

Teachers actively use their voices in interactive (social) contexts (Arvaja, 2016) to adopt different I-positions in professional life. Each I-position is considered a temporal teacher's distinct voice situated in a specific setting. A particular teacher's voice represents a set of utterances denoting how to engage in a specific scenario. A specific teacher's I-position entails positioning in his/her social and intrapsychological dimensions (Gülerce et al., 2014) and is shaped by two components. The first is the I or subject-position, which can be defined as the first-person perspective from which the world and the self are perceived, experienced and evaluated. It provides the subject with a sense of freedom, initiative and personal agency, and it is what identifies us as subjects. The second is the position, which is a particular current social and institutional function that can be developed by teachers in culture, society, communities, or institutions. The identity of a particular teacher can be described based on a dynamic multiplicity of relatively autonomous but interrelated I-positions in the landscape of his/her human mind (Hermans, Kempen, \& Van Loon, 1992); therefore, a teacher's I-position is considered a subjective expression of his/her teacher identity (Raggatt, 2015).

The dialogical self-approach involves at least two different teacher learning mechanisms: renaming experience and reconstructing practice (Freeman, 1993). Renaming experience involves teachers being critically reflexive, renegotiating and assigning new meanings to their teaching practice, and in this way developing their own voices. Reconstructing practice refers to the process of developing new teaching actions in the classroom and is closely related to 
the notion of teaching I-positions. Table 3 shows the main characteristics of this perspective.

\begin{tabular}{|c|c|c|c|c|}
\hline & $\begin{array}{l}\text { Learning } \\
\text { mechanisms }\end{array}$ & $\begin{array}{c}\text { Programme } \\
\text { content }\end{array}$ & $\begin{array}{l}\text { Purpose of } \\
\text { teacher } \\
\text { education }\end{array}$ & $\begin{array}{l}\text { Instructional } \\
\text { approach }\end{array}$ \\
\hline \multirow{2}{*}{ 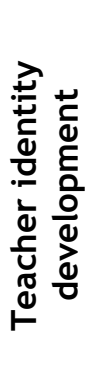 } & $\begin{array}{l}\text { Renaming } \\
\text { experience }\end{array}$ & $\begin{array}{l}\text { Teachers' views } \\
\text { about teaching }\end{array}$ & $\begin{array}{l}\text { To promote } \\
\text { teachers' teaching } \\
\text { sense-making } \\
\text { processes }\end{array}$ & $\begin{array}{l}\text { Teachers' } \\
\text { reflections on } \\
\text { teaching }\end{array}$ \\
\hline & $\begin{array}{l}\text { Reconstructing } \\
\text { practice }\end{array}$ & $\begin{array}{l}\text { The range of I- } \\
\text { positions on } \\
\text { teaching }\end{array}$ & $\begin{array}{c}\text { To promote } \\
\text { changes in existing } \\
\text { teachers' I- } \\
\text { positions on } \\
\text { teaching }\end{array}$ & $\begin{array}{l}\text { Induced, shared, } \\
\text { and dramatized } \\
\text { incidents }\end{array}$ \\
\hline
\end{tabular}

Table 3. Teaching identity development perspective

The first learning mechanism, renaming experience, involves the appropriation of teachers' professional discourse through different dialogical processes and is ultimately intended to promote changes in how teachers make sense of their teaching practices. Teachers' professional discourse is not conceived merely as a set of words, utterances or texts about teaching. Further, it is considered "a sort of 'identity kit' which comes complete with [ways] to act, talk, and often write, to take on a particular social role that others will recognize" (Gee, 1990, p. 142). One well-known means to promote the appropriation of teachers' professional discourse involves developing teachers' reflection on critical incidents in teaching (Badia \& Becerril, 2016).

The second learning mechanism, reconstructing practice, involves reshaping or re-positioning one or more teachers' I-positions. Most teachers start practising from a dominant I-position and gradually, when faced with critical experiences or incidents, re-position (Arvaja, 2016; Branco \& Madureira, 2008). They shift, in the words of Reinekke Lengelle (2016), from a "first story" to a "second story" from which they manifest new I-positions that allow them to better face those critical incidents.

An instructional strategy that has proven effective in re-positioning teachers and fostering these 'second stories' is the "dramatized incident". Due to the emotional value of critical incidents during teaching, this training strategy may have a substantial impact on teachers' mental dynamics and may provoke tensions among teachers' voices and I-positions (Pillen, Beijaard \& Den Brok, 2013). 
Over the last ten years we have investigated the effects of different training devices based on incidents. A first approach focuses on triggering incidents in the classroom. For this approach, researchers (or a teacher colleague) prepare an incident that the teacher considers real since he/she is not aware that an incident has been planned (Monereo, Badia, Bilbao, Cerrato \& Weise, 2009). Though this is a useful and authentic approach, it obviously raises severe deontological concerns.

A second strategy involves the use of anonymous written reports whereby the teacher and students explain what has happened in the classroom and propose changes (Scartezini \& Monereo, 2016). While this method is not intrusive, its efficacy depends on the teacher's willingness to accept criticism.

A third approach involves simulating situations in which teachers must cope with incidents to which they are specially sensitized. In this case, colleagues (usually participants in a shared course or workshop or members of a community of learning) provoke the types of incidents that teachers have struggled with in their teaching (Monereo, Weise \& Álvarez, 2013). This is the most efficient strategy in terms of time (a period of 20 hours) and efficacy (the quantity and quality of changes).

Internal dynamics between the different I-positions provoke a set of interactions with certain regularity that may be described by the type of influence they exert on the rest. Hubert Hermans (2018) has tried to describe and characterise these. Without going into detail, they stand out especially for their power to promote significant identity changes: core I-positions, counter Ipositions, coalitions, third I-positions, over I-positions, promoter and antipromoter I-positions, and meta-positions.

A core I-position is a central position on which the functioning of many other Ipositions depends. A counter I-position is a position that responds to another position from which it is spatially differentiated. Coalitions are I-positions that cooperate and strengthen each other in achieving a particular goal. A third Iposition arises from the conflict between two positions and assumes its resolution in the form of a new negotiated position that reconciles those in dispute. Over I-positions are so overvalued and exaggerated that they hardly have a counter I-position, creating a dangerous imbalance. Promoter positions have been likened to the role of a play's director, who guides, overseas, connects, and can act as an innovator for characters on a stage (Valsiner, 2004). A promoter I-position implies an openness to the future and an ability to harmonize positions that appear and are identified by the meta-position. The promoter Iposition can "reorganize the self towards a higher level of development" and provides room for both continuity and discontinuity in the self (Hermans \& 
Hermans-Konopka, 2010, p. 228). The counter I-position, of course, performs the inverse function.

Finally, Hubert Hermans and Agnieszka Hermans-Konopka (2010, p. 147) characterized meta-positions in the following way: (1) "[a meta-position] permits some distance from the other positions", (2) "provides an overarching view so that several positions can be seen simultaneously and their mutual relationships visible", (3) "makes it possible to see the linkages between positions as part of one's personal history or the collective history of the group or culture to which one belongs" and (4) "facilitates the creation of a dialogical space (in contact with others or oneself) in which positions and counter-positions engage in dialogical relationships".

The dynamic relationships between these different types of I-positions stimulate a continuous intra-psychological tension between movements, which tend to organize and structure the mental space (centring processes) or which destabilize existing forms of organization (processes of decentring), precipitating spaces for change.

Both centring and decentring movements are at the core of what dialogical training and counselling aim to realise, producing changes in teachers' professional identities through tensions between I-positions and their voices. In addition, this dynamic seeks to achieve changes in the voices and identities of a collective group working in coordination or their We-position. A We-position is a position shared by a group of people (e.g., a team of teachers) in relation to an idea, conflict or event (Hermans, 2018).

The trigger the spurs these changes may have its origin in the internal dialogue between positions, but it is often generated from an external factor classified as problematic because it generates individual and/or collective incidents. More specifically, an educational innovation would fully enter this definition as it is a proposal that problematizes an existing situation and causes incidents at both individual and collective levels. We delve into this idea below.

\section{EDUCATIONAL INNOVATIONS AS GENERATORS OF CRITICAL INCIDENTS}

According to the OECD (2016), educational innovation can be defined as:

The act of creating and then disseminating new educational tools as well as new instructional practices, organisational forms and technology. Although innovation is not a research programme, it is often based on research and advances in knowledge and consists in changing processes and practices to improve the quality and productivity of the service which is delivered. (p. 126) 
Therefore, the ultimate goal of educational innovation is to improve what is done in both quality and efficiency.

When educators are asked what innovation means (Room 241, 2018), they refer to effectiveness and efficiency in relation to their students and contribute two new ideas of great interest. On one hand, an attitude of change among participants can promote risk taking and a desire to try alternative ways of solving real problems without fear of failing. This can involve promoting an I-position that some authors have referred to as the "pedagogical innovator" (AvidovUngar \& Forkosh-Baruch, 2018). On the other hand, the entire educational community should participate in a project to achieve more significant commitment and motivation. Courage, motivation and commitment linked to an attitude of change in the educational community seem to be key to facing innovation. However, to prevent this from involving reckless or imprudent action, change must have a strong justification in that it must be essential and have certain guarantees of success in the sense that it is plausible within a particular context.

Situations in which there is consensus on the ways educational agents interpret educational innovation (i.e., they consider it as a viable improvement and accept the challenge of changing their pedagogical principles and practices) are not very common. There are frequently opposing forces, creating barriers to implementation and resulting in failure in many cases (Geijsel, Sleegers, van den Berg, \& Kelchtermans, 2001).

In this sense, we assume that all educational innovations act as generators of incidents or as events that produce emotional imbalances in participants. When a certain incident exceeds a certain threshold, destabilizing the emotional control of individuals and groups, it is a critical incident. Any educational innovation can create tensions among teachers, which necessitates considerable negotiation and agreement between the I-position of each teacher. For this reason, research on teachers and their relationships to educational innovation has become a priority focus over the last twenty years (Ketelaar, Beijaard, Boshuizen, \& Den Brok, 2012).

Research on how teachers perceive innovation has provided relevant information on the conditions that foster the introduction of innovation programmes into schools (Geijsel, Sleegers et al, 2001), the role of teachers' motivations to promote educational innovation (Abrami, Poulsen \& Chambers, 2004), and the obstacles perceived by teachers throughout the innovation process (Stevens, 2004). According to Evelien Ketelaar, Maaike Koopman, Perry Den Brok, Douwe Beijaard and Henry Boshuizen (2014), the process of understanding innovation is an: 
Active cognitive and emotional process in which teachers try to relate information derived from innovation with their knowledge, their beliefs and experiences [...]. This process is dynamic, as teachers use their own identity or frame of reference as a lens to make sense of the innovation [...], but at the same time, their identity or frame of reference can change in the process. (p. 316)

Teachers can experience different degrees of congruence between their beliefs and values regarding innovation and depending on this are less or more likely to be enthusiastic about such innovation. That is, teachers compare their views, beliefs and feelings with respect to their usual practices with the demands and characteristics of the proposed innovation (Spillane, Reiser, \& Reimer, 2002).

From this perspective, all educational innovations require changes in teachers' professional identities, and these changes "imply a relationship between the socio-cognitive construction of new meanings and the creation of individual and emotional senses of new experiences" (Geijsel \& Meijers, 2005, p. 419). Research has also highlighted the interdependence between identity and educational innovation. The introduction of new educational innovations affects the identities of teachers (Beijaard, Meijer, \& Verloop, 2004; Day, Sammons, Stobart, Kington, \& Gu, 2007; Geijsel \& Meijers, 2005), which affects how teachers respond to educational innovations (Schmidt \& Datnow, 2005; Van Veen \& Sleegers, 2006).

In a relatively recent study, Yam Sam Chee, Swati Mehrotra and Jing Chuan Ong (2015) showed how teachers who participate in an innovation process change their identities and how this change reflects the success of innovation. The participants modified their epistemological positions (e.g., by changing their beliefs and practices regarding how to use textbooks in the classroom); praxiological positions (e.g., by changing their ways of relating to their students); ontological positions (e.g., by reflecting on their professional learning), and axiological positions (e.g., by changing their values with respect to certain teaching practices).

There is agreement on the fact that the following four dimensions decisively contribute to identity change in the face of educational innovation (Ketelaar et al., 2012): a) changes related to acquiring new knowledge; b) changes related to sensemaking processes of innovation; c) changes linked to innovation ownership; and d) changes related to agency.

In regard to the acquisition of knowledge, Jay Fogleman, Barry Fishman, and Joe Krajcik (2006) demonstrated the importance of sustaining innovation through leading teachers' learning and of supporting their professional development. In the same vein, Inge Bakkenes, Jan Vermunt, and Theo Wubbels 
(2010) focused on describing teachers' learning activities and outcomes in the context of educational innovation. Moreover, Jianwei Zhang, Huang-Yao Hong, Marlene Scardamalia, Chew Lee Teo, and Elisabeth A. Morley (2011) explored teachers' knowledge-building processes as a critical principle based on innovation in primary schools.

Recent contributions focus on the process of fostering teachers' sensemaking and on exploring how coordinating groups of a curriculum are involved in processes of sensemaking and negotiation (Pietarinen, Pyhältö, \& Soini, 2017; Soini, Pietarinen, \& Pyhältö, 2018). These authors studied educational innovation activities associated with the implementation of education reforms across the Finnish education system. Findings drawn from longitudinal focus groups and interviews reveal that coordination groups have used several complementary strategies to develop a shared understanding of district-level curricula through comparison, standardization, and transformation.

Likewise, teachers' feelings of ownership over educational innovation are also considered an essential characteristic of teachers' positions on innovation (Ketelaar et al., 2014). Teachers' ownership reflects the degree to which teachers support innovative ideas. Teachers with high levels of ownership have a sense of pride about innovation, feel a need to change their practices, are willing to invest time and energy in innovation and tend to express their identification with innovation by, for instance, describing their individual experiences to colleagues. Finally, sociality is related to teachers belonging to teams and specific institutions adopting certain goals, forms of organization and forms of interaction. This sociality has a significant influence on the development of professional identity (Vangrieken, Dochy, Raes, \& Kyndt, 2015). As a result, educational innovations can become a part of teacher professional identity and can contribute to its sustainability.

Ketelaar et al. (2014) distinguished between two groups of teachers, engaged and reserved groups, using as a criterion teachers' positioning on new pedagogies. Overall, engaged teachers exhibited more indications of ownership than those of the reserved group and more active and explicit ways of making sense of their experiences according to a new pedagogy. Moreover, both groups demonstrated high degrees of agency though this manifested in different ways. The engaged teachers often described the link between the goals they had set for themselves and their related learning experiences while the reserved teachers often simply described the situations that they had initiated.

Finally, the notion of teacher agency refers to "the active search for professional development and learning through the objectives of a teacher" (Beauchamp \& Thomas, 2009, p. 177). As stated by different works (Vähäsantanen, 
2015), educational innovations are successful when they rely on professionals who express a high level of agency. Teachers with a strong sense of agency show a sufficient level of autonomy in their work and feel that they can guide and self-control sensemaking processes and make decisions about the process of educational innovation. In addition, teachers feel that they can handle potential inconsistencies between their views and beliefs and the process of educational innovation.

Innovation appears both at the intra-psychological and group levels or in individual teachers' identities and the identities of groups of teachers. As Hubert Hermans (2018) pointed out in a recent publication, Self and Identity are social but also societal. Society is found in the self, and the self and identities are also observed in society:

It is my purpose to demonstrate that society, rather than being an "external" causal factor, is manifesting itself in the self and receiving there an answer from the same self. Self meets society in itself and, in turn, the society meets the self in itself. Along these lines, I want to show that it is possible to bring self and society closer together (p. 19)

From our perspective, the concept of the We-position comes into play. Remember that we are referring to a collective I-position or a position shared by a group of people such as a team of teachers. As Hermans (2018) highlights, "the emergence of extended We-positions requires open and flexible boundaries between group identities allowing dialogical relationships to emerge needed for the production of new and common meanings" (p. 135). Accordingly, the emergence of these We-positions requires producing generative dialogue through which personal I-positions, at the level of the individual, and Wepositions, at the group level, should be open to creative exploration and learning from one another to achieve something new and better. In conclusion, assessing the impact of educational innovation and recording and analysing changes that occur reciprocally among participating teachers and in the groups in which they work (i.e., in I- and We-positions) reflect systems of more effective valuation.

As pointed out in the previous section, such a significant and profound change in the conceptions, strategies and feelings of participants implies a change in their identity or a change in their individual I-positions and in the We-position as a collective. As many contributions have emphasized (Akkerman \& Meijer, 2011; Assen, Koops, Meijers, Otting \& Poell, 2018; Beijaard et al., 2004; Kunnen \& Metz, 2015; MacLure, 1993; Meeus, Van de Schoot, Keijsers, Schwartz, \& Branje, 2010; Sachs, 2005), teachers' professional identities at the individual and group levels are the most critical indicator of a teacher's behaviour and 
thinking. A teacher's identity serves as a lens through which a teacher justifies and makes sense of his/her interpretations, decisions and practices.

\begin{tabular}{|c|c|c|c|c|c|}
\hline & Filip & Berta & Eva & Ivan & Christine \\
\hline 듬ำ & $\begin{array}{c}\text { Advisor } \\
\text { He is the school } \\
\text { psychologist of the } \\
\text { centre and attends } \\
\text { meetings as an ob- } \\
\text { server and supervi- } \\
\text { sor of the innova- } \\
\text { tion. }\end{array}$ & $\begin{array}{l}\text { Early Teacher } \\
\text { She has just arrived } \\
\text { at the centre and } \\
\text { the team this year } \\
\text { and is willing to } \\
\text { learn. Ivan is his } \\
\text { mentor, whom she } \\
\text { respects, but she } \\
\text { wants to do new } \\
\text { things and admires } \\
\text { Christine's initia- } \\
\text { tive. }\end{array}$ & $\begin{array}{c}\text { Expert Teacher } \\
\text { She is an excellent } \\
\text { teacher and a re- } \\
\text { nowned historian } \\
\text { with prestigious } \\
\text { publications and } \\
\text { occasional partici- } \\
\text { pation in the mass } \\
\text { media. }\end{array}$ & $\begin{array}{l}\text { Institutional Leader } \\
\text { He is the coordina- } \\
\text { tor of the depart- } \\
\text { ment, essentially } \\
\text { because he is a } \\
\text { friend of the cen- } \\
\text { tre's director, who } \\
\text { put him in charge. }\end{array}$ & $\begin{array}{l}\text { Charismatic Leader } \\
\text { She was once the } \\
\text { principal of the } \\
\text { centre, and she is } \\
\text { highly respected by } \\
\text { most teachers for } \\
\text { her innovative ide- } \\
\text { as and empathy in } \\
\text { personal relation- } \\
\text { ships. }\end{array}$ \\
\hline 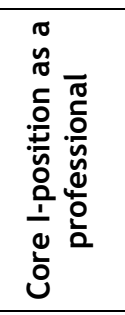 & $\begin{array}{c}\text { He aims to provide } \\
\text { all resources neces- } \\
\text { sary for the innova- } \\
\text { tion to be success- } \\
\text { ful. }\end{array}$ & $\begin{array}{l}\text { She considers her- } \\
\text { self a student of } \\
\text { veteran teachers } \\
\text { and enjoys the } \\
\text { teaching profes- } \\
\text { sion. }\end{array}$ & $\begin{array}{l}\text { She considers her- } \\
\text { self a researcher } \\
\text { and teacher of his- } \\
\text { tory. }\end{array}$ & $\begin{array}{c}\text { He considers him- } \\
\text { self a defender of } \\
\text { true history that } \\
\text { must be transmit- } \\
\text { ted to new genera- } \\
\text { tions. }\end{array}$ & $\begin{array}{l}\text { She considers her- } \\
\text { self an innovator in } \\
\text { education and is in- } \\
\text { terested in stu- } \\
\text { dents' learning } \\
\text { outcomes and in us- } \\
\text { ing history to help } \\
\text { them understand } \\
\text { the world. }\end{array}$ \\
\hline 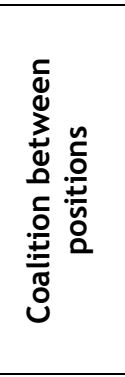 & $\begin{array}{c}\text { He tries to unite } \\
\text { different members } \\
\text { of the department } \\
\text { and especially the } \\
\text { leaders, Ivan and } \\
\text { Christine. }\end{array}$ & $\begin{array}{l}\text { She feels indebted } \\
\text { to Ivan but agrees } \\
\text { more with the ideas } \\
\text { of Christine and } \\
\text { seeks support and } \\
\text { help from Filip. }\end{array}$ & $\begin{array}{c}\text { She sometimes } \\
\text { joins Ivan in de- } \\
\text { fending the central } \\
\text { role of the curricu- } \\
\text { lum and encourages } \\
\text { to Christine to keep } \\
\text { improving every } \\
\text { day. }\end{array}$ & $\begin{array}{l}\text { He is loyal to the } \\
\text { directive team that } \\
\text { has doubts about } \\
\text { the need for inno- } \\
\text { vation. He some- } \\
\text { times joins Eva in } \\
\text { expressing his dis- } \\
\text { trust and believes } \\
\text { that Berta, his pu- } \\
\text { pil, should support } \\
\text { him. }\end{array}$ & $\begin{array}{c}\text { Her leading sup- } \\
\text { porter is Filip, and } \\
\text { as he tries to per- } \\
\text { suade the whole } \\
\text { team to join, she } \\
\text { experiences severe } \\
\text { difficulty with Ivan } \\
\text { and sometimes with } \\
\text { Eva. }\end{array}$ \\
\hline 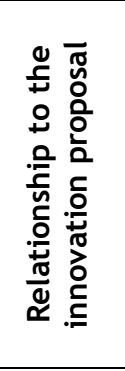 & $\begin{array}{l}\text { He adopts a meta- } \\
\text { position by trying } \\
\text { to put into play the } \\
\text { most appropriate I- } \\
\text { positions for the } \\
\text { team's objectives. }\end{array}$ & $\begin{array}{l}\text { She tries to adopt a } \\
\text { third I-position that } \\
\text { allows her to rec- } \\
\text { oncile the conflict } \\
\text { between her posi- } \\
\text { tion of subordina- } \\
\text { tion to Ivan and her } \\
\text { role as a supporter } \\
\text { of innovation that } \\
\text { encourages Chris- } \\
\text { tine. }\end{array}$ & $\begin{array}{c}\text { She sometimes pri- } \\
\text { oritizes the curricu- } \\
\text { lum over all other } \\
\text { priorities. }\end{array}$ & $\begin{array}{l}\text { He adopts an anti- } \\
\text { promoter I-position } \\
\text { based on the prem- } \\
\text { ise that innovation } \\
\text { can eliminate con- } \\
\text { tent and lower the } \\
\text { demand and there- } \\
\text { fore is sceptical. }\end{array}$ & $\begin{array}{l}\text { She clearly adopts } \\
\text { an I-position that } \\
\text { promotes innova- } \\
\text { tion. }\end{array}$ \\
\hline 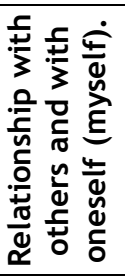 & $\begin{array}{l}\text { He mainly tries to } \\
\text { negotiate with Ivan } \\
\text { and Eva. On the } \\
\text { other hand, with } \\
\text { Christine and Berta, } \\
\text { he tends to use } \\
\text { more generative } \\
\text { dialogue. }\end{array}$ & $\begin{array}{l}\text { She tries to negoti- } \\
\text { ate with Ivan with } \\
\text { little success. With } \\
\text { Filip he tends to } \\
\text { debate while with } \\
\text { Eva and Christine } \\
\text { he tends to negoti- } \\
\text { ate. }\end{array}$ & $\begin{array}{l}\text { She tries to per- } \\
\text { suade Berta and Fil- } \\
\text { ip while negotiating } \\
\text { with Ivan and Chris- } \\
\text { tine. }\end{array}$ & $\begin{array}{l}\text { He tries to per- } \\
\text { suade Eva. With } \\
\text { Berta, he some- } \\
\text { times uses a com- } \\
\text { manding tone. With } \\
\text { Filip and Christine, } \\
\text { he debates. }\end{array}$ & $\begin{array}{l}\text { She tries to avoid } \\
\text { debating with Ivan } \\
\text { and Eva and to ne- } \\
\text { gotiate with them } \\
\text { and Berta. With Fil- } \\
\text { ip, the dialogue is } \\
\text { more generative. }\end{array}$ \\
\hline
\end{tabular}

Table 4. Participants' characteristics in a case of educational innovation

Traditionally, educational innovations have been evaluated using descriptors and external, general and quantitative indicators such as the number of people involved in educational innovation, satisfaction with changes according to sur- 
veys, the number of students who pass state exams, etc. All of these are shortterm and superficial measures that do not appropriately reveal the profound, structural and persistent changes that innovation might have produced.

To observe, record and analyse the evolution of the I-positions of participants and their corresponding We-positions, we propose two representation techniques. On one hand, the Personal Repertoire of Positions developed by Hubert Hermans (2001) helps us visualize the trajectory that each participant follows during innovation, which is individually considered but socially connected through external positions or others-in-me. On the other hand, a community Plot represents the evolution of a group of teachers as a team. In the next section we present a case based on some of our previous research data to illustrate our analysis.

\section{THE RELATIONSHIP BETWEEN I-POSITIONS, WE-POSITIONS AND EDUCATIONAL INNOVATION. AN ILLUSTRATIVE CASE}

Imagine a teaching team belonging to the social sciences department of a secondary school and composed of five professors. This year, the team has decided to initiate an educational innovation that involves learning through the development of an authentic project linked to service to the community and carried out collectively. Table 4 summarizes the characteristics of the participants.

To represent the different types of relations observed between I-positions within this group of teachers, we use a set of symbols shown in Figure 1.

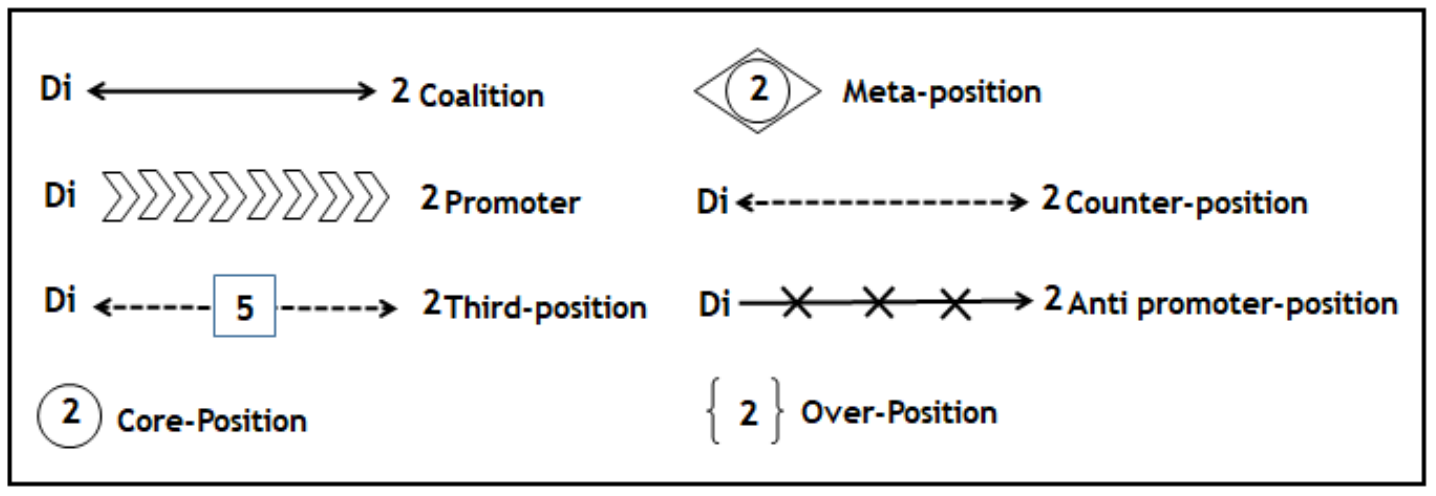

Figure 1. Relations between I-positions

Their personal repertoires of positions (PPR, by Hermans, 2001) are as follows:

- Filip, advisor (Figure 2) 


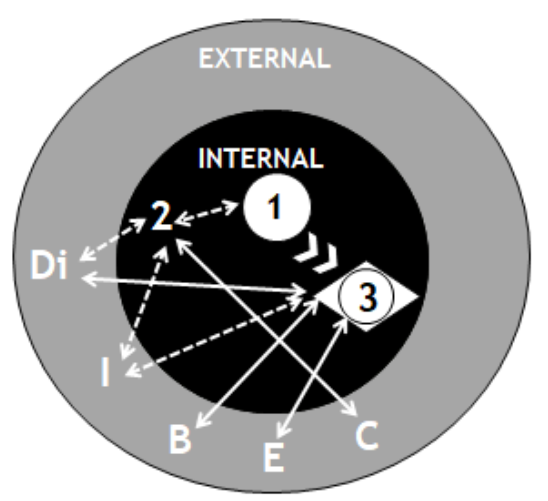

Internal Positions (Me)
1: I as an advisor
2: I as an innovative
3: I as a mediator

External Positions
(others-in-me)
Di: Direction Team
B. Berta
E: Eva
I: Ivan
C: Christine

Figure 2. Filip's Personal Positions Repertoire

Filip holds a peripheral role in the team and behaves like a follower. His central I-position as an advisor is to be committed to the team of teachers in the social sciences department. For this reason, he frequently interacts with them but also with the rest of the teaching centre teams. His institutional position forces him to maintain a certain level of neutrality by acting as a mediator of all teams and their members. However, his interest in innovation creates conflicts between him and the school principal and especially with Ivan, who does not consider him neutral. The main contribution that he can make is to transform his I-position as a mediator into a meta-position. This shift allows him to be aware of the relationships that he has with each role and to decide what forms of dialogue might best cater to each partner or to at least agree on tasks, possibilities, and limits.

- Berta, Early Teacher (Figure 3)

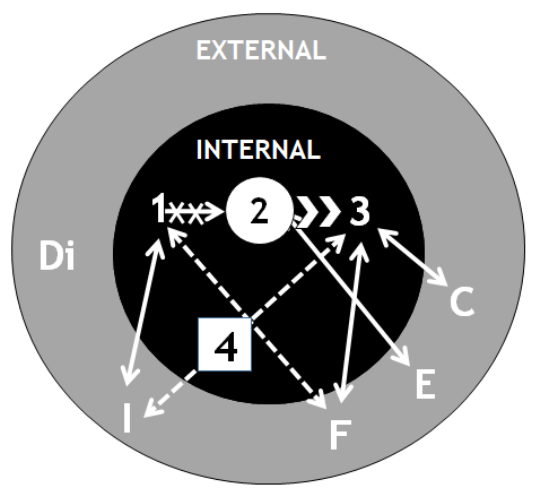

Internal Positions (Me)

1: I as a subordinate

2: I as a vocational

3: I as an innovative

4: I as an Expert innovative

\section{External Positions}

(others-in-me)

Di: Direction Team

F. Filip

E: Eva

I: Ivan

C: Christine

Figure 3. Berta's Personal Positions Repertoire 
Berta is the newest team member (as a beginner) and therefore is still undergoing socialization and integration. Her subordination to Ivan creates a significant conflict. While she owes her gratitude and loyalty to him because he has continually endorsed her, a vocational position dominates and leads her to value the innovative approaches of Christine and to admire Eva's expertise.

In this case, it would be advisable for Berta to develop the third I-position as an innovative expert. In this way, she could communicate better with the different interlocutors as a historian and teacher who wants to continuously develop herself.

- Eva, Expert Teacher (Figure 4)

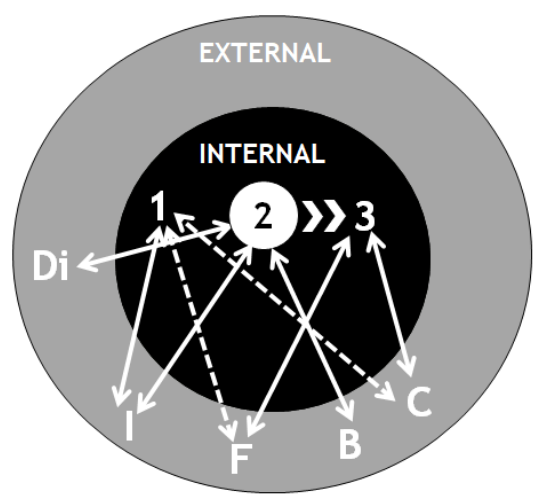

Internal Positions (Me)
1: I as a History Expert
2: I as a Researcher
3: I as a Vocational

External Positions
(others-in-me)
Di: Direction Team
F. Filip
B: Berta
I: Ivan
C: Christine

Figure 4. Eva's Personal Positions Repertoire

Eva is the most widely recognized person in the academic field. She shares the role of expert with other team members, but she stands out in her position as a researcher, which is her core I-position. This position affords her a prestigious role in the team and promotes her vocational position by providing her satisfaction in and out of school. However, her non-negotiable defence of complete and rigorous content produces certain tensions with Christine and Filip. In any case, Eva appears as one of the main bridges between the most conservative perspectives of the team and the most innovative ones.

- Ivan, Leader (Institutional) (Figure 5)

Ivan leads the antagonistic position with those who defend the proposed educational innovation. He has a strong influence on Berta, maintains a relationship of respect with Eva and has achieved the confidence of the principal. His imposed leadership acts as an anti-promoter in his relationship with Christine, one of the most popular teachers at the centre. This situation is worsened by one of Ivan's central views on the pivotal role of teachers in the classroom as 


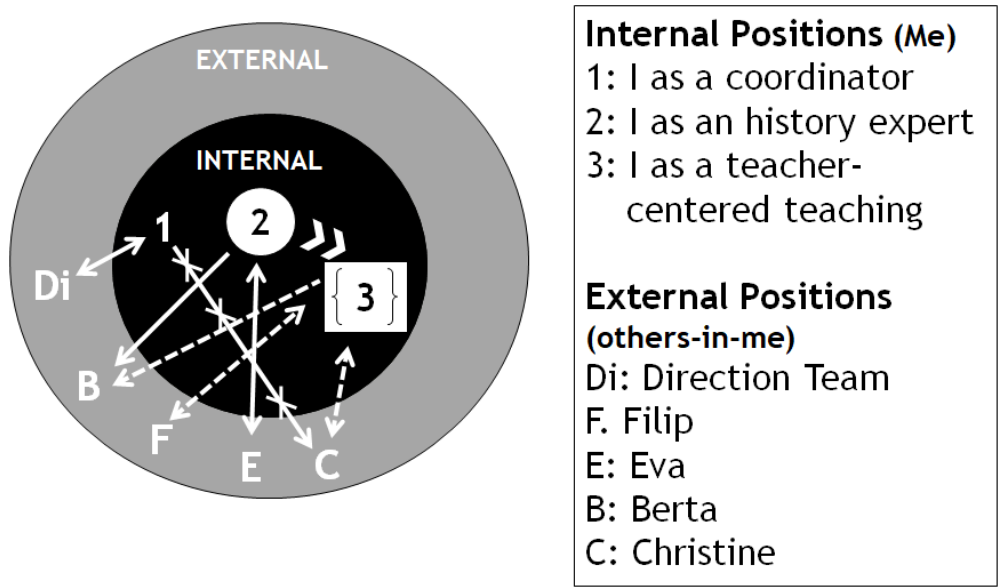

Figure 5. Ivan's Personal Positions Repertoire

specialists of a subject rather than as educators. This over I-position may represent the main obstacle to reaching an agreement with Ivan. Persuading Ivan to construct a counter I-position in relativizing the role of the teacher as the absolute authority of the classroom would be one of the main changes required for the smooth running of the team.

- Christine, Leader (Charismatic) (Figure 6)

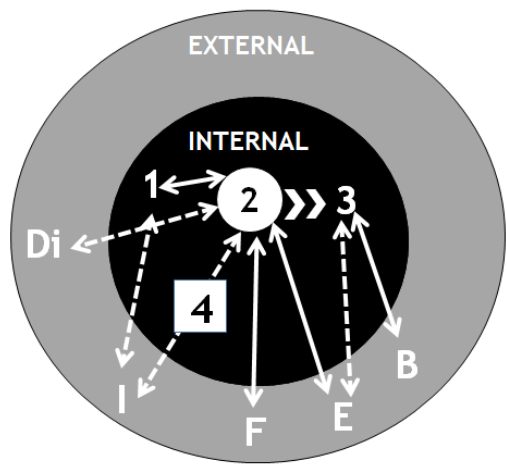

Internal Positions (Me)
1: I as a recognized leader
2: I as an innovative
3: I as a student-centered
$\quad$ teaching
4: I as a content defender
External Positions
(others-in-me)
Di: Direction Team
F. Filip
E: Eva
I: Ivan
B: Berta

Figure 6. Christine's Personal Positions Repertoire

Christine is the leading promoter of the change implied by the proposed innovation. Her popularity makes her a natural leader whose point of view holds considerable weight in the team and the institution. Her main allies are Filip and Berta, and she maintains a good relationship with Eva. On the other hand, her primary opponent, with whom she has experienced ongoing conflict, is 
Ivan. By extension, the director of the school also holds particular reservations about her views of change and innovation, which, in addition to representing a risk to the centre's image, may question his own leadership. Given that Christine is also a relevant historian, it would be advisable for her to elaborate a third I-position that involves applying specific disciplinary expertise. This change of position and attitude could bring her even closer to Eva and Berta and especially to Ivan.

On this point we can imagine a critical incident that could become the formal complaint of a group of parents to the school principal. Parents may believe that their children are not learning history with enough rigour and depth due to them engaging in learning projects with collaborative groups. This situation produces a "process of decentring" that disorganizes the respective self and creates spaces for change (e.g., Ivan must decide if he should support his department colleagues in front of the parents). The evolution of each of the team members also affects the team's position as an interdependent global system (We-position).

To observe and analyse the evolution of a team of teachers and take into account dimensions that promote the change in identity mentioned above (i.e., changes in the team's knowledge and organization, commitment to innovation and decision-making and execution), we consider three main axes:

1- As an organizational and political community, the members of the group share, to a greater or lesser extent, their knowledge regarding:

a) Group history, institutional hierarchies, networks of power and the influence of each member's implicit and explicit rules of functioning.

b) Prototypical incidents and ways to cope with them.

c) The distribution of roles and tasks, ways to make and execute decisions, and ways of rewarding or penalizing actions.

Leaders would tend to occupy the centre of the group because they have a stronger influence on decisions. Moreover, their net influence is frequently stronger.

Centrality and influence are the two main variables for visualizing power. To represent the power and influence of each group member, we use two tools. First, we use a layout (in black and white images) to identify areas of influence. A similar plot pattern means that there is mutual influence. Second, spatial positions in the graph illustrate the power of each member. Positioning close to the centre denotes having more power while positioning on the periphery can be interpreted as having less power. 
2- As a learning and discursive community, team members share, to a greater or lesser extent, knowledge regarding feelings of ownership and sensemaking in relation to an educational innovation: objectives, theories and authors, key concepts, ways to evaluate the impact of innovation, and expected results. The thickness of arrows graphically represents levels of agreement on educational innovation where a thicker arrow denotes stronger agreement on the innovation project.

3- The group members, as part of an interactive community, opt for or privilege certain kinds of dialogue to establish relationships. This dialogue can be, for example, more commanding or persuasive or more negotiated and generative. In the first case, a subordinated relation is assumed whereas in the second, a parallel relation occurs. This dimension is related to the ways in which group members exercise agency. In this case, the form of dialogue between two team members is denoted by unidirectional (with a single arrowhead) and bidirectional arrows (with two arrowheads) and by solid and dashed arrow lines. A bidirectional arrow with a solid line denotes a more democratic mode of dialogue while a unidirectional arrow with a dashed line denotes a more authoritarian form of communication.

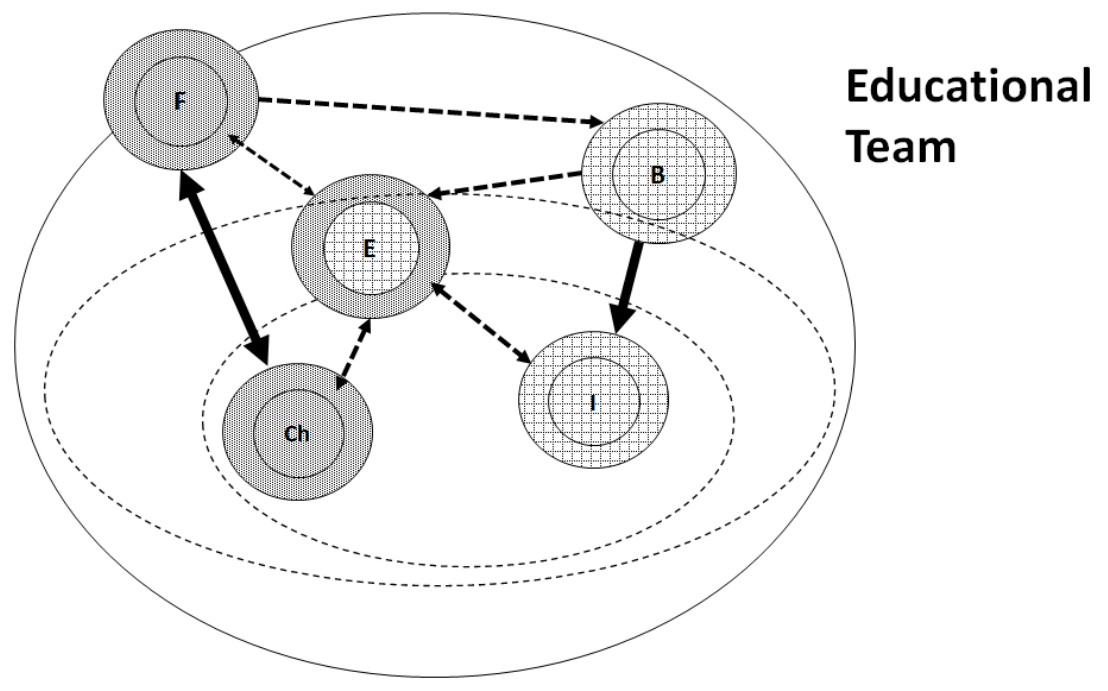

Figure 7. Teacher Team Community Identity Plot

When we examine the team's evolution at a certain point in time (Figure 7), we can analyse the relationships between its members and ultimately its current We-position. A We-position would denote balanced conditions with two distinct forces of influence: that involving Filip and Christine and that involving Ivan and Berta. As an essential difference, while the first relationship main- 
tains a similar discourse and bidirectional form of democratic communication, in the second relationship, Berta is subordinate to Ivan and the form of dialogue that prevails involves an imbalance of power. We also observe that Eva is related to both groups and occupies an equidistant position. She is central to negotiation and therefore begins to acquire more power and assume a more central role in the team.

In any case, the forced assimilation of all members with the innovation may have negative consequences. As noted by Bosma and Kunnen (2001): "Too much assimilation results in rigidity and distortion of reality, while too much accommodation results in chaotic and superficial commitments" (p. 55). Wenger himself, who introduced the concept of communities of practice, in his latest publications (Wenger-Trayner, Fenton-O'Creevy, Kubiak, Hutchinson, \& WengerTrayner, 2014) stresses the importance of resolving tensions between the need to meet both individual needs and group objectives. He argues for the balancing of different positions and that rather than seeking absolute consensus, it is better to encourage engagement and the construction of a team identity that is much more, he affirms, than mere belonging or sharing particular interests.

In the near future, we intend to apply this analytic framework in a way that allows us to not only observe the systemic and reciprocal evolution of a group and its members but to also intervene in and achieve a balance that favours a positive impact of educational innovation.

\section{CONCLUDING REMARKS}

The implementation of educational innovation has become a common practice when it seeks to improve the quality of education in a specific educational system. A significant amount of research has explored the variables and factors that influence implementation and relationships to the characteristics of students and teachers involved in this process.

For students involved in educational innovation, analytical frameworks most frequently used have been based on quantitative external measures related to students' outcomes such as improvements in their performance, their results on national and international tests, their rates of entry into the workforce, or their perceived satisfaction with innovation. It is also well recognized that several of teachers' characteristics are related to the implementation of educational innovation, including their efficacy, self-concept and attitudes (Guskey, 1988); experience and efficacy (Ghaith \& Yaghi, 1997) and levels of motivation (Abrami et al., 2004). 
The dialogical self-approach applied in teacher professional identity research and illustrations of how dialogical Self Theory can be used to analyse the positioning of individual professionals in educational innovation may deepen our understanding of how the process of educational change works under real conditions in three ways.

First, the dialogical self-approach allows us to relate individual, group and community levels of educational change. This multilevel approach may further research on dynamics of change in real settings in which representatives of educational administrations, educational leaders, principals, parents and teachers participate.

Second, the notion of the I-position allows us to establish an integrative view of a teacher's internal (subjective dimension) and external dimensions (teaching practice), overcoming theoretical constructs that separately focus on teacher changes (e.g., a teacher's knowledge) or classroom activities (e.g., teaching practices, learning processes and outcomes, and significant and critical incidents).

Third, the dialogical self-approach allows us to carry out research that considers time based on trajectories followed by a group of people involved in a common task at the individual and group levels.

As the main limitation of this theoretical and methodological approach, we have not yet been able to develop a broader application to real settings. Future research in this field would allow us to gain a deeper understanding of three processes: a) how the theoretical framework of the dialogical selfapproach operates in practice to explain dynamics of change in real scenarios; b) to what extent methodological tools linked to the dialogical self-approach are useful for collecting and analysing evidence of changes in contexts of educational innovation; and c) the actual impact of theoretical and applied knowledge derived from this kind of research.

\section{REFERENCES}

Abd-El-Khalick, Fouad \& Akerson, Valarie L. (2004). Learning as conceptual change: Factors mediating the development of preservice elementary teachers' views of nature of science. Science Education, 88(5), 785-810.

https://doi.org/10.1002/sce.10143

Abd-El-Khalick, Fouad \& Lederman, Norman G. (2000). Improving science teachers' conceptions of nature of science: A critical review of the literature. International Journal of Science Education, 22(7), 665-701. https://doi.org/10.1080/09500690050044044 
Abrami, Philip C; Poulsen, Catherine \& Chambers, Bette (2004). Teacher motivation to implement an educational innovation: Factors differentiating users and non-users of cooperative learning. Educational Psychology, 24(2), 201-216.

https: / / doi.org/10.1080/0144341032000160146

Admiraal, Wilfried; Hoeksma, Mark; van de Kamp, Marie-Thérèse \& van Duin, Gee (2011). Assessment of teacher competence using video portfolios: Reliability, construct validity, and consequential validity. Teaching and Teacher Education, 27(6), 1019-1028. https://doi.org/10.1016/j.tate.2011.04.002

Akkerman, Sanne F. \& Meijer, Paulien C. (2011). A dialogical approach to conceptualizing teacher identity. Teaching and Teacher Education, 27(2), 308-319.

https://doi.org/10.1016/j.tate.2010.08.013

Arvaja, Maarit (2016). Building teacher identity through the process of positioning. Teaching and Teacher Education, 59, 392-402.

https://doi.org/10.1016/j.tate.2016.07.024

Assen, Hanneke; Koops, Hilda; Meijers, Frans; Otting, Hans \& Poell, Rob (2018). How can a dialogue support teachers' professional identity development? Harmonising multiple teacher I-positions. Teaching and Teacher Education, 73, 130-140. https://doi.org/10.1016/j.tate.2018.03.019

Avidov-Ungar, Orit \& Forkosh-Baruch, Alona (2018). Professional identity of teacher educators in the digital era in light of demands of pedagogical innovation. Teaching and Teacher Education, 73, 183-191. https://doi.org/10.1016/j.tate.2018.03.017

Avramidis, Elias \& Norwich, Brahm (2002). Teachers' attitudes towards integration/inclusion: a review of the literature. European Journal of Special Needs Education, 17(2), 129-147. https://doi.org/10.1080/08856250210129056

Badia, Antoni \& Becerril, Lorena (2016). Renaming teaching practice through teacher reflection using critical incidents on a virtual training course. Journal of Education for Teaching, 42(2), 224-238. https://doi.org/10.1080/02607476.2016.1143146

Bakkenes, Inge; Vermunt, Jan D. \& Wubbels, Theo (2010). Teacher learning in the context of educational innovation: Learning activities and learning outcomes of experienced teachers. Learning and Instruction, 20(6), 533-548.

https://doi.org/10.1016/j.learninstruc.2009.09.001

Beauchamp, Catherine \& Thomas, Lynn (2009). Understanding teacher identity: An overview of issues in the literature and implications for teacher education. Cambridge Journal of Education, 39(2), 175-189.

https://doi.org/10.1080/03057640902902252

Beijaard, Douwe (2017). Learning teacher identity in teacher education. In Jean Clandinin \& Jukka Husu (Eds.). The SAGE handbook of research on teacher education (pp. 139-142). London: SAGE Publications. https://doi.org/10.4135/9781526402042

Beijaard, Douwe; Meijer, Paulien \& Verloop, Nico (2004). Reconsidering research on teachers' professional identity. Teaching and Teacher Education, 20(2), 107-128. https: / / doi.org/10.1016/j.tate.2003.07.001

Beijaard, Douwe; Verloop, Nico \& Vermunt, Jan D. (2000). Teachers' perceptions of professional identity: An exploratory study from a personal knowledge perspective. Teaching and Teacher Education, 16(7), 749-764. https://doi.org/10.1016/s0742$\underline{051 \times(00) 00023-8}$ 
Blomberg, Geraldine; Sherin, Miriam Gamoran; Renkl, Alexander; Glogger, Inga \& Seidel, Tina (2014). Understanding video as a tool for teacher education: investigating instructional strategies to promote reflection. Instructional Science, 42(3), 443463. https://doi.org/10.1007/s11251-013-9281-6

Bosma, Harke A. \& Kunnen, E. Saskia (2001). Determinants and mechanisms in Ego identity development: a review and synthesis. Developmental Review, 21(1), 39-66. https://doi.org/10.1006/drev.2000.0514

Branco, Angela \& Madureira, Ana F. (2008). Dialogical Self in action: The emergence of Self-Positions among complex emotional and cultural dimensions. Estudios de Psicología, 29(3), 319-332. https:// doi.org/10.1174/021093908786145377

Butler, Deborah L. \& Schnellert, Leyton (2012). Collaborative inquiry in teacher professional development. Teaching and Teacher Education, 28(8), 1206-1220. https: / / doi.org/10.1016/j.tate.2012.07.009

Chee, Yam Sam; Mehrotra, Swati \& Ong, Jing Chuan (2015). Professional development for scaling pedagogical innovation in the context of game-based learning: Teacher identity as cornerstone in "shifting" practice. Asia-Pacific Journal of Teacher Education, 43(5), 423-437. https://doi.org/10.1080/1359866x.2014.962484

Cochran-Smith, Marilyn \& Lytle, Susan L. (1999). Relationships of knowledge and practice: Teacher learning in communities. Review of Research in Education, 24, 249305. https: //doi.org/10.2307/1167272

Collet-Sabé, Jordi (2017). I do not like what I am becoming but...: transforming the identity of head teachers in Catalonia. Journal of Educational Policy, 32(2), 141-158. https://doi.org/10.1080/02680939.2016.1253873

Day, Christopher; Sammons, Pam; Stobart, Gordon; Kington, Alison \& Gu, Qing (2007). Teachers matter: Connecting lives, work and effectiveness. Maidenhead: Open University Press.

Ertmer, Peggy A. (2005). Teacher pedagogical beliefs: The final frontier in our quest for technology integration? Educational Technology Research and Development, 53(4), 25-39. https://doi.org/10.1007/bf02504683

Fogleman, Jay; Fishman, Barry \& Krajcik, Joe (2006). Sustaining innovations through lead teacher learning: A learning sciences perspective on supporting professional development. Teaching Education, 17(2), 181-194.

https: / / doi.org/10.1080/10476210600680416

Freeman, Donald (1993). Renaming experience/reconstructing practice: Developing new understanding of teaching. Teaching and Teacher Education, 9(5-6), 85-497. https://doi.org/10.1016/0742-051x(93)90032-c

Gaete Vergara, Marcela (2018). A look at secondary student teachers' fears between reproduction and transformation. Profesorado -Revista de curriculum y formación del profesorado, 22(1), 501-517.

Gee, James (1990). Social linguistics and literacies: Ideology in discourses. Philadelphia: Falmer. https://doi.org/10.1016/0898-5898(91)90011-7

Geijsel, Femke; Sleegers, Peter; van den Berg, Rudolf \& Kelchtermans, Geert (2001). Conditions fostering the implementation of large-scale innovation programs in 
schools: Teachers' perspectives. Educational Administration Quarterly, 37(1), 130166. https: //doi.org/10.1177/00131610121969262

Geijsels, Femke \& Meijers, Frans (2005). Identity learning: The core process of educational change. Educational Studies, 31(4), 419-430.

https: / / doi.org/10.1080/03055690500237488

Ghaith, Ghazi \& Yaghi, Hussein (1997). Relationships among experience, teacher efficacy, and attitudes toward the implementation of instructional innovation. Teaching and Teacher Education, 13(4), 451-458. https://doi.org/10.1016/s0742$\underline{051 \times(96) 00045-5}$

Gülerce, Aydan; Baerveldt, Cor; Gillespie, Alex; Martin, Jack; Raggatt, Peter \& Zittoun, Tania (2014). A polylogue? Where and how to move with and in dialogue? New Ideas in Psychology, 32, 80-87.

https://doi.org/10.1016/j.newideapsych.2013.05.002

Guskey, Thomas R. (1988). Teacher efficacy, self-concept, and attitudes toward the implementation of instructional innovation. Teaching and Teacher Education, 4(1), 63-69. https://doi.org/10.1016/0742-051x(88)90025-x

Hatton, Neville \& Smith, David (1995). Reflection in teacher education: Towards definition and implementation. Teaching and Teacher Education, 11(1), 33-49. https: / / doi.org/10.1016/0742-051x(94)00012-u

Hayward, Louise \& Spencer, Ernest (2010). The complexities of change: formative assessment in Scotland. Curriculum Journal, 21(2), 161-177. https://doi.org/10.1080/09585176.2010.480827

Heick, Terry (2019) 12 barriers to innovation in education. Retrieved from: https://www.teachthought.com/the-future-of-learning/12-barriers-innovationeducation/.

Hermans, Hubert J. M. (2001). The construction of a personal position repertoire: Method and practice. Culture \& Psychology, 7(3), 323-365. https://doi.org/10.1177/1354067x0173005

Hermans, Hubert J. M. (2018). Society in the Self. A theory of identity in democracy. Oxford: Oxford University Press. https://doi.org/10.1093/oso/9780190687793.001.0001

Hermans, Hubert J. M. , \& Hermans-Konopka, Agnieszka (2010). Dialogical Self Theory: Positioning and counter-positioning in a globalizing society. Cambridge, UK: Cambridge. https: //doi.org/10.1017/cbo9780511712142

Hermans, Hubert J. M.; Kempen, Harry J. \& Van Loon, Rens J. (1992). The dialogical self: beyond individualism and rationalism. American Psychologist, 47(1), 23-33. https: / / doi.org/10.1037/0003-066x.47.1.23

Ivanova, Natalia \& Popova, Elena (2017). Professionals and the problem of implementing innovation in university. Educational Studies Moscow, 1, 184-206.

https://doi.org/10.17323/1814-9545-2017-1-184-206

Jennings, Patricia A. \& Greenberg, Mark T. (2009). The prosocial classroom: Teacher social and emotional competence in relation to student and classroom outcomes. $R e$ view of Educational Research, 79(1), 491-525. https://doi.org/10.3102/0034654308325693 
Ketelaar, Evelien; Beijaard, Douwe; Boshuizen, Henny P. \& Den Brok, Perry J. (2012). Teachers' positioning towards an educational innovation in the light of ownership, sense-making and agency. Teaching and Teacher Education, 28(2), 273-282. https://doi.org/10.1016/j.tate.2011.10.004

Ketelaar, Evelien; Koopman, Maaike; Den Brok, Perry J.; Beijaard, Douwe \& Boshuizen, Henry P. (2014). Teachers' learning experiences in relation to their ownership, sense-making and agency. Teachers and Teaching, 20(3), 314-337. https: / / doi.org/10.1080/13540602.2013.848523

Kim, Min Kyu; Xie, Kui \& Cheng, Sheng-Lun (2017). Building teacher competency for digital content evaluation. Teaching and Teacher Education, 66, 309-324. https://doi.org/10.1016/j.tate.2017.05.006

Kunnen, Saskia \& Metz, Marijke (2015). Commitment and exploration: The need for a developmental approach. In Kate C. McLean, \& Moin Syed (Eds.), The Oxford handbook of identity development (pp. 125-131). Oxford, UK: Oxford University Press. https://doi.org/10.1093/oxfordhb/9780199936564.001.0001

Leaman, Lori Hostetler \& Flanagan, Toni Michele (2013). Authentic role-playing as situated learning: Reframing teacher education methodology for higher-order thinking. Studying Teacher Education, 9(1), 45-61. https://doi.org/10.1080/17425964.2013.771573

Lengelle, Reinekke (2016). What a career coach can learn from a playwright: Expressive dialogues for identity development. In Hubert Hermans (Eds). Assessing and Stimulating a Dialogical Self in Groups, Teams, Cultures, and Organizations (pp. 3753). Cham: Springer. https://doi.org/10.1007/978-3-319-32482-1_3

Levin, Barbara \& He, Ye (2008). Investigating the content and sources of teacher candidates' personal practical theories (PPTs). Journal of Teacher Education, 59(1), 5568. https://doi.org/10.1177/0022487107310749

MacLure, Maggie (1993). Arguing for yourself: Identity as an organising principle in teachers' jobs and lives. British Educational Research Journal, 19(4), 311-323. https: / / doi.org/10.1080/0141192930190401

Meeus, Wim; Van de Schoot, Rens; Keijsers, Loes; Schwartz, Seth J. \& Branje, Susan (2010). On the progression and stability of adolescent identity formation: A fivewave longitudinal study in early-to-middle and middle-to-late adolescence. Child Development, 81(3), 1565-1581. https://doi.org/10.1111/j.1467-8624.2010.01492.x

Monereo, Carles; Badia, Antoni; Bilbao, Gilda; Cerrato, Maria \& Weise, Crista (2009). Ser un docente estratégico: cuando cambiar la estrategia no basta. Cultura y Educación, 21(3), 237-256. https://doi.org/10.1174/113564009789052343

Monereo, Carles; Weise, Crista \& Alvarez, Ibis (2013). Changing university teacher's identity: training based on dramatized incidents. Infancia y Aprendizaje, 36(3), 323340. https: / / doi.org/10.1174/021037013807533043

OECD (2016). Innovating education and educating for innovation: The power of digital technologies and skills. Paris: OECD Publishing. https://doi.org/10.1787/9789264265097-en

Peterson, Cynthia \& Bond, Nathan (2004). Online compared to face-to-face teacher preparation for learning standards-based planning skills. Journal of Research on 
Technology in Education, 36(4), 345-360. https://doi.org/10.1080/15391523.2004.10782419

Pietarinen, Janne; Pyhältö, Kirsi \& Soini, Tiina (2017). Large-scale curriculum reform in Finland - exploring the interrelation between implementation strategy, the function of the reform, and curriculum coherence. The Curriculum Journal, 28(1), 22-40. https: / / doi.org/10.1080/09585176.2016.1179205

Pillen, Marieke; Beijaard, Douwe \& Den Brok, Perry (2013). Professional identity tensions of beginning teachers. Teachers and Teaching, 19(6), 660-678. https: / / doi.org/10.1080/13540602.2013.827455

Piwowar, Valentina; Thiel, Felicitas \& Ophardt, Diemut (2013). Training inservice teachers' competencies in classroom management. A quasi-experimental study with teachers of secondary schools. Teaching and Teacher Education, 30, 1-12. https://doi.org/10.1016/j.tate.2012.09.007

Putnam, Ralph T. \& Borko, Hilda (2000). What do new views of knowledge and thinking have to say about research on teacher learning? Educational Researcher, 29(1), 4-15. https://doi.org/10.3102/0013189x029001004

Raggatt, Peter T. F. (2015). Positioning: dialogical voice in mind and culture. Theory \& Psychology, 25(6), 775-797. https://doi.org/10.1177/0959354315590850

Rivas, Axel (2017). Cambio e innovación educativa: las cuestiones cruciales. Buenos Aires: Fundación Santillana.

Room 241 (2018, March 16). Bloc of Concordia University of Portland. Innovation in Education: What Does It Mean, and What Does It Look Like? March 16, 2018. https://education.cu-portland.edu/blog/classroom-resources/educationalinnovations-roundup/

Rovegno, Inez (1992). Learning a new curricular approach: Mechanisms of knowledge acquisition in preservice teachers. Teaching and Teacher Education, 8(3), 253-264. https://doi.org/10.1016/0742-051x(92)90024-w

Sachs, Judyth (2005). Teacher education and the development of professional identity: Learning to be a teacher. In Pam Denicolo \& Michael Kopf (Eds.), Connecting policy and practice: Challenges for teaching and learning in schools and universities (pp. 221). Oxford: Routledge.

Sadovnikova, Nadezhda \& Ahmedov, Mirza (2019). Relevant concepts of a teacher's state when experiencing professional identity crisis. Education and Science, 21(2), 113-131. https://doi.org/10.17853/1994-5639-2019-2-113-131

Scartezini, Raquel \& Monereo, Carles (2016). The development of university teachers' professional identity: a dialogical study. Research Papers in Education, 33(1), 42-58. https://doi.org/10.1080/02671522.2016.1225805

Schmidt, Michèle \& Datnow, Amanda (2005). Teachers' sense-making about comprehensive school reform: The influence of emotions. Teaching and Teacher Education, 21, 949-965. https://doi.org/10.1016/j.tate.2005.06.006

Soini, Tiina; Pietarinen, Janne \& Pyhältö, Kirsi (2018). Shared sense-making strategies in curriculum reform: district-level perspective. Improving Schools, 21(2), 111-126. https://doi.org/10.1177/1365480217744290 
Spillane, James; Reiser, Brian \& Reimer, Todd (2002). Policy implementation and cognition: Reframing and refocusing implementation research. Review of Educational Research, 72, 387-431. https://doi.org/10.3102/00346543072003387

Stevens, Robert J. (2004). Why do educational innovations come and go? What do we know? What can we do? Teaching and Teacher Education, 20(4), 389-396. https://doi.org/10.1016/j.tate.2004.02.011

Toom, Auli; Husu, Jukka \& Patrikainen, Sanna (2015). Student teachers' patterns of reflection in the context of teaching practice. European Journal of Teacher Education, 38(3), 320-340. https://doi.org/10.1080/02619768.2014.943731

Trigwell, Keith; Prosser, Michael \& Waterhouse, Fiona (1999). Relations between teachers' approaches to teaching and students' approaches to learning. Higher Education, 37(1), 57-70. https://doi.org/10.1023/A:1003548313194

Twyford, Kaye; Le Fevre, Deidre \& Timperley, Helen (2017). The influence of risk and uncertainty on teachers' responses to professional learning and development. Journal of Professional Capital and Community, 2(2), 86-100. https://doi.org/10.1108/jpcc10-2016-0028

Vähäsantanen, Katja (2015). Professional agency in the stream of change: Understanding educational change and teachers' professional identities. Teaching and Teacher Education, 47, 1-12. https://doi.org/10.1016/j.tate.2014.11.006

Valsiner, Jaan (2004). The promoter sign: Developmental transformation within the structure of the dialogical self. In XVIII biennial meeting of the international society for the study of behavioral development, Ghent, july 11-15.

Van Veen, Klaas \& Sleegers, Peter (2006). How does it feel? Teachers' emotions in a context of change. Journal of Curriculum Studies, 38, 85-111.

https://doi.org/10.1080/00220270500109304

Vangrieken, Katrien; Dochy, Filip; Raes, Elisabeth \& Kyndt, Eva (2015). Teacher collaboration: A systematic review. Educational Research Review, 15, 17-40. https://doi.org/10.1016/j.edurev.2015.04.002

Warford, Mark K. (2011). The zone of proximal teacher development. Teaching and Teacher Education 27(2), 252-258. https:// doi.org/10.1016/j.tate.2010.08.008

Wenger-Trayner, Etienne; Fenton-O'Creevy, Mark; Hutchinson, Steven; Kubiak, Chhris \& Wenger-Trayner, Beverly (2014). Learning in Landscapes of Practice: Boundaries, identity, and knowledgeability in practice-based learning. Abingdon: Routledge. https://doi.org/10.4324/9781315777122

Westaway, Lise \& Graven, Mellony (2019). Exploring grade 3 teachers' resistance to "take up' progressive mathematics teaching roles. Mathematics Education Research Journal, 31(1); 27-46. https://doi.org/10.1007/s13394-018-0237-7

Zhang, Jianwei; Hong, Huang-Yao; Scardamalia, Marlene; Teo, Chew Lee \& Morley, Elizabeth A. (2011). Sustaining knowledge building as a principle-based innovation at an elementary school. Journal of the Learning Sciences, 20(2), 262-307. https://doi.org/10.1080/10508406.2011.528317 


\section{CARLES MONEREO}

Full professor of Educational Psychology at the Universitat Autònoma de Barcelona. He is currently the coordinator of the SINTE research team. His lines of research focus on the construction of professional identity, teaching and learning strategies, and the analysis of critical incidents in education.

carles.monereo@uab.cat

https: / / orcid.org/0000-0001-7447-985X

\section{ANTONI BADIA}

Full professor of Educational Psychology at the Open University of Catalonia. He is currently involved in some research projects, including the teacher identity and the development of the inquirer-teacher identity in the context of educational innovations. His current research interests also include technology-enhanced learning and learning with online learning environments.

tbadia@uoc.edu

https://orcid.org/0000-0003-1294-8061

\section{FORMATO DE CITACIÓN}

Monereo, Carles \& Badia, Antoni (2020).A dialogical self-approach to understanding teacher identity in times of educational innovations. Quaderns de Psicologia, 22(2), e1572. http://dx.doi.org/10.5565/rev/qpsicologia. 1572

\section{HISTORIA EDITORIAL}

Recibido: 16-09-2019

$1^{a}$ revisión: 02-03-2020

Aceptado: $16-04-2020$

Publicado: $31-08-2020$ 